Research article

\title{
Anti-tumor effect of Liqi, a traditional Chinese medicine prescription, in tumor bearing mice Deng-Bo Ji ${ }^{1}$, Jia Ye ${ }^{* 1}$, Yi-Min Jiang ${ }^{2}$ and Bo-Wen Qian ${ }^{3}$
}

\begin{abstract}
Address: ${ }^{1}$ Department of Molecular and Cellular Pharmacology, School of Pharmaceutical Sciences, Peking University, Beijing, 100191, PR China, ${ }^{2}$ Medical and Healthy Analysis Center, Peking University, Beijing, 100191, PR China and ${ }^{3}$ Department of Traditional Chinese Medicine, Shanghai University of Chinese Traditional Medicine, Shanghai, 201203, PR China
\end{abstract}

Email: Deng-Bo Ji - jidengbo@bjmu.edu.cn; Jia Ye* - yejia@bjmu.edu.cn; Yi-Min Jiang - jiangyimin@bjmu.edu.cn; BoWen Qian - qianbowen@gmail.com

* Corresponding author

Published: I July 2009

BMC Complementary and Alternative Medicine 2009, 9:20 doi:10.1 186/1472-6882-9-20

This article is available from: http://www.biomedcentral.com/1472-6882/9/20

(C) 2009 Ji et al; licensee BioMed Central Ltd.

This is an Open Access article distributed under the terms of the Creative Commons Attribution License (http://creativecommons.org/licenses/by/2.0), which permits unrestricted use, distribution, and reproduction in any medium, provided the original work is properly cited.
Received: 19 August 2008

Accepted: I July 2009

\begin{abstract}
Background: Liqi, an herbal preparation used in traditional Chinese medicine, has been used to treat cancer in China for centuries. We investigated the anti-tumor effects of liqi and their mechanisms in mice that had been xenografted with tumors.

Methods: Sarcoma 180 tumor, Lewis lung carcinoma, and SGC-790I cells were implanted in $\mathrm{BALB} / \mathrm{c}$ mice, C57BL/6 mice, and BALB/C nude mice, respectively. Liqi was administered to subgroups of these mice. The tumor weight and size were measured. Cell cycle analysis and $T$ lymphocyte subsets were determined by flow cytometry. The activity of NK cells and TNF was tested using cytotoxicity assay on YAC-I cells and L929 cells, respectively, and the activity of IL-2 was tested with an IL-2-dependent CTLL-2 cell proliferation assay. Platelet aggregation was monitored by measuring electric impedance, and the levels of thromboxane $\mathrm{A} 2\left(\mathrm{TXA}_{2}\right)$ and prostacyclin $\left(\mathrm{PGI}_{2}\right)$ in blood were measured by ${ }^{125} \mid-\mathrm{TXB}_{2}$ and ${ }^{125} \mid-\mathrm{K}_{\text {eto- }} \mathrm{PGF}_{1 \alpha}$ radioimmunoassay.

Results: The results showed that liqi inhibited tumor growth in tumor-implanted mice and arrested the cell proliferation in the G0/GI phase and reduced the portion of cells in $S$ and G2/M phase for SGC-790I cells. Liqi increased the activity of NK cells and TNF- $\alpha$, stimulated IL-2 production and activity, and regulated $\mathrm{T}$ lymphocyte subpopulations. Liqi inhibited the Lewis lung carcinoma metastasis by inhibiting platelet aggregation and normalizing the balance between $T X A_{2}$ and $\mathrm{PGI}_{2}$.
\end{abstract}

Conclusion: All these findings demonstrated that liqi has an anti-tumor effect in vivo. The mechanism may be related to immune regulation and anticoagulation effects.

\section{Background}

Cancer is a leading cause of death worldwide. The main curative therapies for cancer are surgery and radiation, although these are most successful if the tumor is diagnosed at an early stage. For advanced tumors, chemotherapy is the treatment of choice, and although these drugs are effective, they are associated with severe adverse events and drug resistance [1], and new therapeutic options are needed. In the search for new cancer therapeutics with low toxicity and few side effects, traditional Chinese medicines are promising candidates. 
Liqi prescription, a traditional Chinese medicine made from Poncirus trifoliate (L.)Raf, Akebia Trifoliate Koidz, Citrus medica var. sarcodactylis Swingle and Saussurea lappa, has been used to treat malignancies in traditional Chinese medicine for centuries. The main active constituents are coumarins, flavonoids, and terpenoids in Poncirus trifoliate (L.)Raf; triterpene and triterpenoid saponin in Akebia Trifoliate Koidz; terpene, flavonoids and polysaccharide in Citrus medica var. sarcodactylis Swingle; and sesquiterpenes and sesquiterpene lactones in Saussurea lappa[2-5]. Recent studies have demonstrated their multiple pharmacologic actions, including anti-inflammatory, anti-allergic and antibacterial effects; promoting gastrointestinal motor function; and inhibiting cancer cell growth in vitro. Poncirus trifoliate inhibits human colon cancer HT-29 cell growth and induces human leukemia HL-60 cell apoptosis [6,7]. Akebia Trifoliate Koidz inhibits the growth of breast cancer cell lines MDA-MB-231 and BT-483[8]. Saussurea lappa induces G2-growth arrest and apoptosis in AGS gastric cancer cells [9].

However, little research has been conducted on the antitumor effects of liqi in vivo. In the present experiment, we studied the anti-tumor effect of liqi and explored the mechanism of any effect on tumor-bearing mice.

\section{Methods \\ Materials}

Poncirus trifoliate (L.)Raf, Akebia Trifoliate Koidz, Citrus medica var. sarcodactylis Swingle and Saussurea lappa were purchased from Shanghai Pharmaceutical Co., Shanghai, China, and were authenticated by Prof. Bo-Wen Qian, Department of Traditional Chinese Medicine, Shanghai University of Chinese Traditional Medicine, Shanghai, China. We also used the following materials: Concanavalin A (ConA), lipopolysaccharide (LPS), propidium iodide, ADP (Sigma, St Louis, MO); $\left[{ }^{3} \mathrm{H}\right] \mathrm{TdR}$ (China Institute of Atomic Energy, Beijing, China); human recombinant interleukin-2 (rhIL-2) (Boehringer Mannhein $\mathrm{GmbH}$, Germany); human recombinant tumor necrosis factor (TNF) (Collaborative Biomedical Products, Bedford, MA); FITC-conjugated antibodies to CD3, CD4, CD8 (Pharmingen, Becton Dickinson, Franklin Lakes, NJ); lactic dehydrogenase (LDH) Cytotox assay kit (Promega, Madison, WI); ${ }^{125} \mathrm{I}_{-} \mathrm{TXB}_{2}$ and ${ }^{125} \mathrm{I}_{-}$Keto-PGF ${ }_{1 \alpha}$ radioimmunoassays (RIA kits, Suzhou Medical College, Suzhou, China); RPMI Medium 1640 (Invitrogen, Carlsabad, CA); fetal bovine serum (FBS, HyClone Corporation, Logan, UT).

\section{Cell culture}

Mouse sarcoma 180 tumor cells, Lewis lung carcinoma cells, and human gastric carcinoma cell line SGC-7901 were donated by Shanghai Institute of Materia Medica, Chinese Academy of Sciences (Shanghai, China). YAC-1, CTLL-2, and L929 cells were provided by School of Medi- cine, Shanghai Jiao Tong University (Shanghai, China), and were grown routinely in RPMI-1640 supplemented with $10 \%$ heat-inactivated fetal bovine serum (FBS). The medium was supplemented with $100 \mathrm{U} / \mathrm{mL}$ penicillin and $100 \mathrm{U} / \mathrm{mL}$ streptomycin; $10 \mathrm{ng} / \mathrm{mL}$ rhIL-2 was added in the culture medium of CTLL-2 cells, and the cells were incubated in a humidified atmosphere, with $5 \% \mathrm{CO}_{2}$ in air at $37^{\circ} \mathrm{C}$.

\section{Animals}

Male BALB/c mice and C57BL/6 mice ( 6 to 8 weeks old) were provided by the Department of Shanghai Institute of Planned Parenthood Research, Fudan University, Shanghai, China. The animals were group-housed in a regulated environment $\left(22 \pm 1{ }^{\circ} \mathrm{C}\right.$, relative humidity $\left.60 \pm 5 \%\right)$ with a 12-h light and 12-h dark cycle (08:00-20:00, light). Food and water were given ad libitum. Food pellets meet Feed Standard of Medical Laboratory Animal of China. Food composition is as follows: protein $18-25 \%$, fat $4-$ $5 \%$, calcium $1.0-1.8 \%$, phosphonium $0.6-1.2 \%$, vitamins A $12500-15000 \mathrm{IU} / \mathrm{kg}$, vitamins D $1250-1500 \mathrm{IU} / \mathrm{kg}$, fiber $4-5 \%$ and moisture $8-10 \%$, lysine $0.98-1.42 \%$, cystine $0.76-1.10 \%$, tryptophane $0.22-0.34 \%$.

$\mathrm{BALB} / \mathrm{c}$ strain athymic nu/nu mice were provided by Shanghai Cancer Institute, China. Female mice (6 to 8 weeks old) were used in this study. The animals were maintained in a specific pathogen free animal care facility, under controlled conditions $\left(25 \pm 2{ }^{\circ} \mathrm{C}, 50 \%-60 \%\right.$ relative humidity and 12-hour light cycle). They were fed with autoclaved tap water and food ad libitum. The laboratory animal protocol used for this study was approved by the committee for control and supervision of experimental animals of Shanghai University of Chinese Traditional Medicine.

\section{Preparation of Liqi}

Liqi was prepared as a lyophilized powder of hot water extracts from 4 species of medical herbs: Citrus medica var. sarcodactylis Swingle, Akebia Trifoliate Koidz, Poncirus trifoliata (L.)Raf and Saussurea lappa. Briefly, the above materials were mixed in a ratio of $3: 2: 1.7: 1.7$ and decocted three times with boiling distilled water for $1 \mathrm{~h}$. The decoction was filtered, collected, concentrated, and lyophilized. The yield of liqi was approximately $20 \%$. Liqi was dissolved in distilled water and administered in a volume of $10 \mathrm{ml} / \mathrm{kg}$. In this experiment, the animal dose of liqi was dose of crude drug.

\section{Tumor models and in vivo treatment regimen}

Sarcoma 180 tumor cells were subcutaneously implanted $\left(2 \times 10^{6} \mathrm{~S} 180\right.$ tumor cells suspended in $50 \mu \mathrm{l}$ of $\mathrm{Ca}^{2+}$ and $\mathrm{Mg}^{2+}$-free phosphate-buffered saline [PBS]) in the right axillary region of syngeneic BALB/c mice. Lewis lung carcinoma cells were subcutaneously implanted $\left(2 \times 10^{6}\right.$ LLC tumor cells suspended in $50 \mu \mathrm{l}$ of PBS) in the right axillary 
region of syngeneic C57BL/6 mice. SGC-7901 cells were subcutaneously implanted $\left(2 \times 10^{5}\right.$ cells suspended in 0.2 $\mathrm{ml}$ of PBS) in the right axillary region of BALB/c nude mice. After $24 \mathrm{~h}$, they were weighed and randomized into 5 groups (12 mice each): a normal control group, a group that was injected with tumor cells but treated with water only, and three groups that were injected with tumor cells and treated with different doses of liqi $(12.5,25$ and $50 \mathrm{~g} /$ $\mathrm{kg}$ ). Treatments were administrated at about 9 o'clock daily by gavage, and mice were weighted daily.

\section{Anti-tumor activity}

On day 21, all mice were weighed and euthanized, and tumors were removed and weighed. The tumor repression rate was calculated as follows: The repression rate $(\%)=$ (mean weight of tumors of water-treated mice - mean weight of tumors of liqi-treated mice)/mean weight of tumors of water-treated mice $\times 100 \%$ [10] .

\section{Cell cycle analysis of SGC-790 I cells from xenografted mice}

For cell cycle analysis, cells were harvested from xenografted $\mathrm{BALB} / \mathrm{c}$ nude mice. On day 21 , tumor tissues were immediately removed and disaggregated in PBS and filtered through a double layer of stainless-steel mesh using a syringe plunger to obtain single cell suspension. Cell cycle distribution was evaluated by propidium iodide staining of nuclei and flow cytometric analysis [11]. Briefly, pelleted cells were washed twice with PBS and then fixed in $70 \%$ cold ethanol overnight at $-20^{\circ} \mathrm{C}$. After washing again, the cells were resuspended in PBS containing RNase A $(200 \mu \mathrm{g} / \mathrm{mL})$ and incubated at $37^{\circ} \mathrm{C}$ for 30 min. Propidium iodide was added to the cell suspensions at a final concentration of $100 \mu \mathrm{g} / \mathrm{mL}$. The fluorescence intensity of PI was analyzed with a FACS calibur flow cytometer (FACS Calibur; Becton Dickinson, USA) and Cell Quest software.

Flow cytometry for peripheral blood $T$ lymphocyte subsets On day 12, the heparinized peripheral blood was collected from the orbital plexuses of the tumor-bearing C57BL/6 mice to analyze peripheral blood lymphocyte subsets by flow cytometry. Samples were prepared by adding $5 \mu \mathrm{l}$ of fluorescent monoclonal antibodies against CD3, CD4, and CD8 to $100 \mu \mathrm{l}$ of heparinized whole blood. CD3+CD4+ (T helper cells) and CD3+CD8+ (T suppressor cells) were counted. Lymphocytes were separated from erythrocytes lysed. The tubes were placed on ice in the dark until flow cytometric analysis; five thousand cells were collected for each sample, and data were analyzed by using flow cytometry.

\section{IL-2 activity assay}

In order to determine the effects of Liqi on IL-2 production and activity, splenic lymphocytes from tumor bearing $\mathrm{BALB} / \mathrm{c}$ mice were prepared after treatment with liqi $(50 \mathrm{~g} /$ $\mathrm{kg}$ ) for 12 days as described above. Spleens of mice were removed under sterile conditions and disaggregated in PBS and filtered through a double layer of stainless-steel mesh using a syringe plunger to obtain single-cell suspension. Lymphocytes were collected and suspended in RPMI-1640 medium at a concentration of $1 \times 10^{7}$ cells $/ \mathrm{mL}$, with ConA added to a final concentration of $5 \mu \mathrm{g} / \mathrm{mL}$. After incubating at $37^{\circ} \mathrm{C}$ and $5 \% \mathrm{CO}_{2}$ for 24 hours, cells supernatants containing extracellular IL-2 were collected and stored at $-20^{\circ} \mathrm{C}$ until assay.

IL-2 activity was tested using an IL-2-dependent CTLL-2 cell proliferation assay [12]. The CTLL-2 cells were washed in medium containing 2\% FBS and incubated for $2 \mathrm{~h}$ without IL-2. The cells were then cultured $\left(1 \times 10^{5}\right.$ cells/ $\mathrm{mL}$ ) in 96-well plates with $0.6 \mathrm{ng} / \mathrm{mL}$ of rhIL-2 or with spleen cell supernatant for $24 \mathrm{~h}$. Six hours before the end, $0.5 \mu \mathrm{Ci}\left[{ }^{3} \mathrm{H}\right] \mathrm{TdR} 50 \mu \mathrm{L}$ was added to each well. The $\left[{ }^{3} \mathrm{H}\right] \mathrm{TdR}$ incorporation was measured with a liquid-scintillator (Beckman Co, USA) counting technique. The results were described as the average of triplicate $\mathrm{Bq}$ (specific radioactivity of [ $\left.{ }^{3} \mathrm{H}\right] \mathrm{TdR}$ was $20 \mu \mathrm{Ci} / \mathrm{mmol}$ ).

\section{Evaluation of NK cell cytotoxicity}

NK cells from tumor bearing BALB/C mice spleens were prepared as described above and used as effector cells. YAC-1 cells, mouse lymphoma sensitive to NK cells were used as target cells. Effector and target cells resuspended in RPMI-1640 medium were added to each well of a 96-well round-bottom microculture plate in triplicate to obtain an effector/target (E/T) ratio of 100:1 and incubated for $16 \mathrm{~h}$. The amount of released lactate dehydrogenase (LDH) in culture supernatants was determined using the LDH Cytotox assay kit according to the manufacturer's instructions. The OD was read at $490 \mathrm{~nm}$ with a Microplate Reader. The percentage of NK cell cytotoxicity was calculated with the formula: cytotoxicity $(\%)=($ experimental release - effector spontaneous release - target spontaneous release)/ (target maximum release - target spontaneous release) $\times$ 100. Experimental release stood for LDH that was released from cocultures at an E/T ratio of 100:1, effector spontaneous release or target spontaneous release was spontaneous LDH release from effector or target cells incubated with medium alone, and target maximum release was obtained from target cells lysed with the lysis solution [13].

\section{Production and activity assay of TNF}

On day 12 , tumor-bearing BALB/c mice received $20 \mu \mathrm{g} /$ $0.2 \mathrm{ml}$ of LPS intravenously. After $1.5 \mathrm{~h}$, blood samples were collected from the orbital plexuses of the mice. The sera were stored at $-20^{\circ} \mathrm{C}$ until used for the TNF assay. TNF activity was determined by a cytotoxicity assay on L929 cells [14]. Briefly, L929 cells were plated at the density of $3.5 \times 10^{4} / \mathrm{ml}$ in 96-well plates and incubated at $37^{\circ} \mathrm{C}$ in a $5 \% \mathrm{CO}_{2}$ atmosphere for $24 \mathrm{~h}$. Samples or 
recombinant TNF (as the standard) were incubated for a further $24 \mathrm{~h}$, in the presence of $2 \mu \mathrm{g} / \mathrm{ml}$ actinomycin $\mathrm{D}$. Cell survival was determined by measuring optical density at $630 \mathrm{~nm}$ after crystal violet staining. The diluted samples were assayed in triplicate. The percentage of cell destruction at a particular dilution was calculated as $\left(\mathrm{A}_{\text {cont }}-\mathrm{A}_{\text {dil }} /\right.$ $\left.A_{\text {cont }}\right) \times 100$, where $A_{\text {cont }}$ is absorbance in control wells and $A_{\text {dil }}$ is absorbance in wells of a particular dilution of sample. The percent cytotoxicities were plotted against the logarithm of sample quantity. One unit of TNF activity was defined as the sample quantity required to achieve $50 \%$ cytotoxicity in the reaction.

\section{Inhibition of Metastasis in Mice}

The tumor-bearing C57BL/6 mice were sacrificed on the 21 st day. Lungs were removed and fixed in $4 \%$ formalin. Tumor colonies were counted under microscope $(\times 200)$.

\section{Platelet Aggregation Assay}

Platelet aggregation was monitored by measuring electric impedance [15] using a whole-blood aggregometer (model OX-200; Shanghai Medical University Instrument Factory, Shanghai, China). On day 21, heparinized blood was drawn from tumor-bearing C57BL mice by cardiac puncture. Whole blood was then diluted with an equal amount of normal saline. The sample was placed in a plastic cuvette containing a magnetic stir bar and was kept at $37^{\circ} \mathrm{C}$ for 5 minutes before analysis. The platelet aggregation was then initiated by adding $10 \mu \mathrm{l} 2 \mu \mathrm{mol} / \mathrm{L}$ ADP and monitored for up to 5 minutes.

\section{Measurement of TXA ${ }_{2}$ and $\mathrm{PGI}_{2}$}

On day 21, blood samples were collected from the femoral artery of the tumor-bearing $\mathrm{C} 57 \mathrm{BL} / 6$ mice and transferred into a plastic tube prefilled with EDTA- $\mathrm{Na}_{2}(9: 1)$. The tube was centrifuged at $1200 \times \mathrm{g}$ at $4^{\circ} \mathrm{C}$ for $10 \mathrm{~min}$. The supernatant was frozen at $-20^{\circ} \mathrm{C}$. $\mathrm{TXA}_{2}$ with a half-life of approximately $30 \mathrm{sec}$ under physiologic conditions was measured using its stable metabolite $\mathrm{TXB}_{2}$, and $\mathrm{PGI}_{2}$ using its stable metabolite 6-keto-prostaglandin F1 $\alpha$ [16]. All determinations were performed using commercially available ${ }^{125} \mathrm{I}_{-} \mathrm{TXB}_{2}$ and ${ }^{125}$ I-Keto-PGF1 $\alpha$ radioimmunoassays (RIA kits, Suzhou Medical College, Suzhou, China).

\section{Statistical analysis}

The data are expressed as mean \pm S.D. Student's t-test or Dunnet $t$-test was used to compare the differences between treated groups and control groups, and differences were considered significant at $\mathrm{P}<0.05$.

\section{Results \\ Effect of liqi on tumor growth in the tumor-transplanted mice}

To explore the role of liqi on tumor growth in mouse Sarcoma 180 transplanted into BALB/c mice and Lewis lung carcinoma transplanted into $\mathrm{C} 57 \mathrm{BL} / 6$ mice, we treated tumor-bearing mice with various doses of liqi $(12.5,25$, $50 \mathrm{~g} / \mathrm{kg}$ ). For Sarcoma 180-bearing BALB/c mice, liqi significantly decreased the tumor growth, with $29.69 \%$ inhibition at $25 \mathrm{~g} / \mathrm{kg}$ and 34.54\% inhibition at $50 \mathrm{~g} / \mathrm{kg}(p<$ 0.05 , Table 1). For Lewis lung carcinoma-bearing C57BL/ 6 mice, liqi significantly decreased the tumor growth, with $35.20 \%$ inhibition at $25 \mathrm{~g} / \mathrm{kg}$ and $42.54 \%$ inhibition at 50 $\mathrm{g} / \mathrm{kg}(p<0.05$, Table 2$)$. There was no significant difference between the body weight of the liqi-treated group and that of the normal group.

To determine whether liqi could suppress human gastric carcinoma growth in vivo, we implanted SGC-7901 in nude mice. As shown in Figure 1, Liqi $(50 \mathrm{~g} / \mathrm{kg}$ ) reduced the tumor weight significantly compared with the model group $(p<0.05)$, with inhibition $27.42 \%$.

\section{Effect of Liqi on SGC-790 I cells cycle from xenografted mice}

As shown in Table 3, cell cycle analysis showed accumulation of SGC-7901 cells in the G0/G1 phase $(p<0.01)$ and decreased cell numbers in the $S(p<0.01)$ and $\mathrm{G} 2 / \mathrm{M}$ phases in mice treated with $50 \mathrm{~g} / \mathrm{kg}$ of liqi.

\section{Effect of liqi on T lymphocyte subpopulations in tumor- bearing mice}

As shown in Figure 2, the numbers of CD3+ CD4+ T cells and the CD4+/CD8+ ratios in peripheral blood were consistently lower in the tumor-bearing mice than in the normal mice $(P<0.05)$. Among tumor-bearing mice, those treated with liqi had consistently higher percentages of

Table I: Effect of Liqi on mouse Sarcoma 180 transplanted into BALB/c mice

\begin{tabular}{|c|c|c|c|c|}
\hline Groups & Doses (g/kg) & $\mathbf{n}$ & Mean weight of tumor (g) & Inhibition (\%) \\
\hline Normal & 0 & 12 & 0 & 0 \\
\hline Model & 0 & 12 & $1.65 \pm 0.47$ & 0 \\
\hline \multirow[t]{3}{*}{ Liqi } & 12.5 & 12 & $1.28 \pm 0.50$ & $22.42 \%$ \\
\hline & 25 & 12 & $1.16 \pm 0.49 *$ & $29.69 \%$ \\
\hline & 50 & 12 & $1.08 \pm 0.50^{*}$ & $34.54 \%$ \\
\hline
\end{tabular}

Each group consists of 12 mice. Results are presented as mean \pm S.D. $* \mathrm{P}<0.05$, compared with model group. 
Table 2: Effect of Liqi on mouse Lewis lung carcinoma transplanted into C57BL/6 mice.

\begin{tabular}{|c|c|c|c|c|}
\hline Groups & Doses (g/kg) & $\mathbf{n}$ & Mean weight of tumor (g) & Inhibition (\%) \\
\hline Normal & 0 & 12 & 0 & 0 \\
\hline Model & 0 & 12 & $1.57 \pm 0.62$ & 0 \\
\hline \multirow[t]{3}{*}{ Liqi } & 12.5 & 12 & $1.11 \pm 0.51$ & $29.06 \%$ \\
\hline & 25 & 12 & $1.02 \pm 0.48^{*}$ & $35.20 \%$ \\
\hline & 50 & 12 & $0.90 \pm 0.44^{*}$ & $42.54 \%$ \\
\hline
\end{tabular}

Each group consists of 12 mice. Results are presented as mean \pm S.D. $* \mathrm{P}<0.05$, compared with model group.

CD3+CD4+ T lymphocytes than did untreated mice $(P<$ $0.05)$. A similar difference was seen in the ratios of CD $4+/$ CD8+; however, the percentages of CD3+CD8+ T lymphocytes were slightly lower in liqi-treated mice.

\section{Effect of liqi on IL-2 activity in tumor-bearing mice}

To illustrate whether liqi could affect the IL-2 production and activity in splenocytes, the murine T-cell line CTLL-2 was used. As shown in Figure 3, splenocytes supernatants from tumor-bearing mice inhibited the proliferation of CCLL-2 cells compared with the normal group $(P<0.01)$. After treatment with liqi (50 g/kg), splenocyte supernatants showed a greater proliferation of CCLL- 2 cells than in splenocytes from untreated mice $(\mathrm{P}<0.01)$.

Effect of liqi on NK cell cytotoxicity in tumor-bearing mice The activation of NK cells is a good indicator of antitumor effect. After tumor-bearing mice were treated with liqi (50

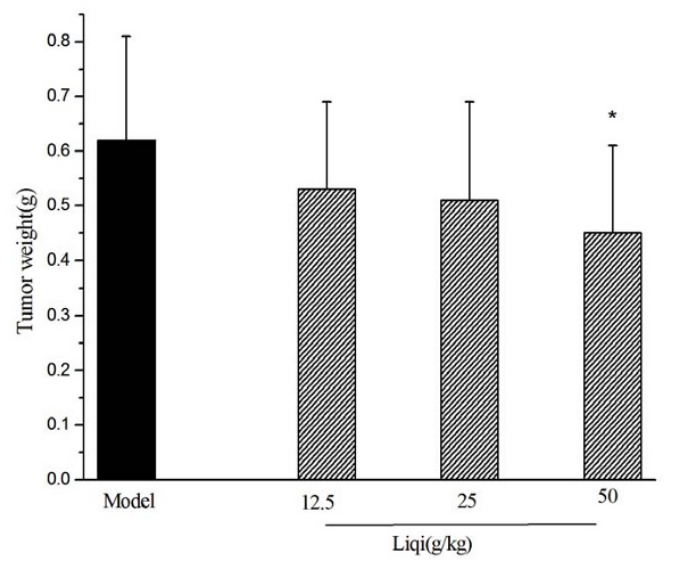

Figure I

Effect of Liqi on SGC790 I transplanted into BALB/C nu/nu mice. SGC-790 I cells were subcutaneously implanted $\left(2 \times 10^{5}\right.$ cells suspended in $0.2 \mathrm{ml}$ of PBS $)$ in the right axillary region of BALB/c nude mice. After $24 \mathrm{~h}$, Liqi $(12.5,25,50 \mathrm{~g} / \mathrm{kg})$ was administrated daily by gavage for 2 I days. The tumor weight was measured. Results are expressed as the mean \pm S.D. of 12 mice. $* P<0.05$, compared with untreated control of tumor-transplanted animals (model group). $\mathrm{g} / \mathrm{kg}$ ), splenic lymphocytes showed more cytotoxicity than did splenocytes from untreated mice $(P<0.05)$ (Figure 4). These results indicate that liqi increased NK cell cytotoxicity.

\section{Effect of liqi on TNF- $\alpha$ activity in tumor-bearing mice} We checked whether Liqi interfered in the LPS-induced TNF- $\alpha$ activity in tumor bearing mice. As shown in Figure 5 , Liqi ( $50 \mathrm{~g} / \mathrm{kg}$ ) significantly increased TNF- $\alpha$ cytotoxicity on L929 cells $(P<0.01)$.

\section{Effect of liqi on metastasis of tumor cells to the lung}

As shown in Figure 6, liqi prevented metastases to the lung. Fewer tumor colonies were observed in the lungs of mice treated with liqi compared with untreated mice $(P<$ $0.05)$. The inhibition effect was $33.89 \%$.

Effect of liqi on platelet aggregation in tumor-bearing mice As shown in Figure 7, increased platelet aggregation was observed in tumor-bearing mice compared with the normal group $(P<0.05)$; however, liqi $(50 \mathrm{~g} / \mathrm{kg})$ significantly decreased platelet aggregation compared with untreated mice $(P<0.05)$.

\section{Effect of liqi on $\mathrm{TXA}_{2}$ and $\mathrm{PGI}_{2}$ in tumor-bearing mice}

As shown in Table $4, \mathrm{TXB}_{2}$ concentration was increased and 6 -Keto-PGF ${ }_{1 \alpha}$ was decreased in the blood plasma of tumor-bearing mice compared with normal group $(P<$ $0.01)$; consequently, the ratio of $\mathrm{TXB}_{2}$ to 6 -Keto-PGF $1 \alpha$ was significantly increased compared with that of the normal group $(P<0.01)$. However, when the tumor-bearing mice were treated with liqi $(50 \mathrm{~g} / \mathrm{kg})$, the level of $\mathrm{TXB}_{2}$ was markedly lowered, 6-Keto-PGF ${ }_{1 \alpha}$ was raised, and the ratio

Table 3: Effect of Liqi on cell cycle of SGC-790 I cells from xenografted mice.

\begin{tabular}{llllll}
\hline Groups & Dose(g/kg) & $\mathbf{n}$ & \multicolumn{3}{c}{ Cell cycle (\%) } \\
\cline { 3 - 6 } & & & GI & S & G2+M \\
\hline Model & 0 & 7 & $49.7 \pm 6.8$ & $44.9 \pm 6.6$ & $5.4 \pm 0.76$ \\
Liqi & 50 & 7 & $61.8 \pm 6.4^{* *}$ & $34.0 \pm 5.3 * *$ & $4.13 \pm 1.2$ \\
\hline
\end{tabular}

Each group consists of 7 mice. Results are presented as mean \pm S.D. **P $<0.01$, compared with model group. 


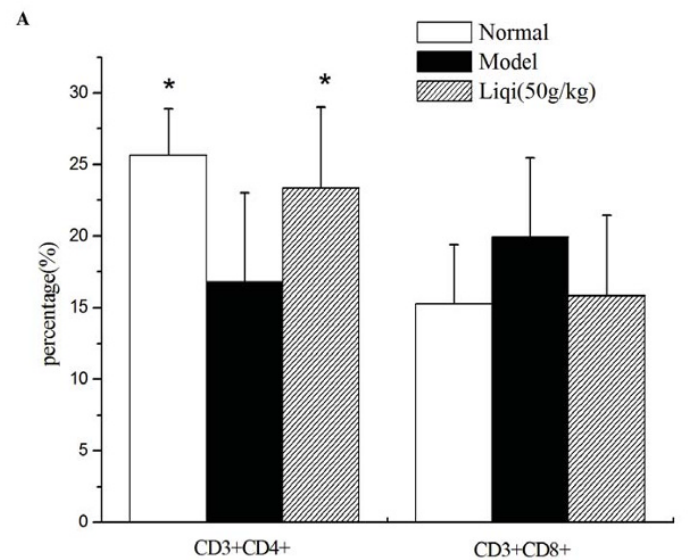

B

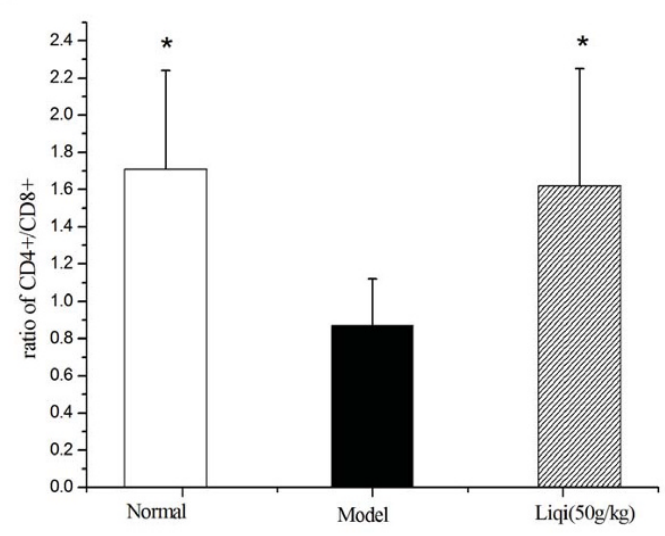

Figure 2

Effect of Liqi on $\mathbf{T}$ lymphocyte subpopulations in tumor-bearing mice. Sarcoma 180 tumor cells were subcutaneously implanted $\left(2 \times 10^{6}\right.$ cells suspended in $50 \mu \mathrm{l}$ of $\mathrm{PBS})$ in the right axillary region of syngeneic BALB/c mice. After $24 \mathrm{~h}$, Liqi $(50 \mathrm{~g} / \mathrm{kg})$ was administrated daily by gavage for 12 days. Peripheral blood lymphocyte subsets were measured by flow cytometry. Results are expressed as the mean \pm S.D. of 12 mice. $* P<0.05$, compared with untreated control of tumor-transplanted animals (model group). The normal group indicates healthy animals without tumor xenograft for comparison.

of $\mathrm{TXB}_{2}$ to 6 -Keto-PGF ${ }_{1 \alpha}$ was significantly decreased compared with untreated mice $(P<0.01)$.

\section{Discussion}

Our findings suggest that liqi has a significant anti-tumor effect against Sarcoma 180 tumor and Lewis lung carcinoma, which is likely because of its immune-modulating effects. Liqi enhanced NK cell activity, increased the Th/Ts ratio, stimulated the production and activity of IL-2 in splenocytes, and increased TNF- $\alpha$ activity in serum. Moreover, liqi inhibited the Lewis lung carcinoma metastasis,

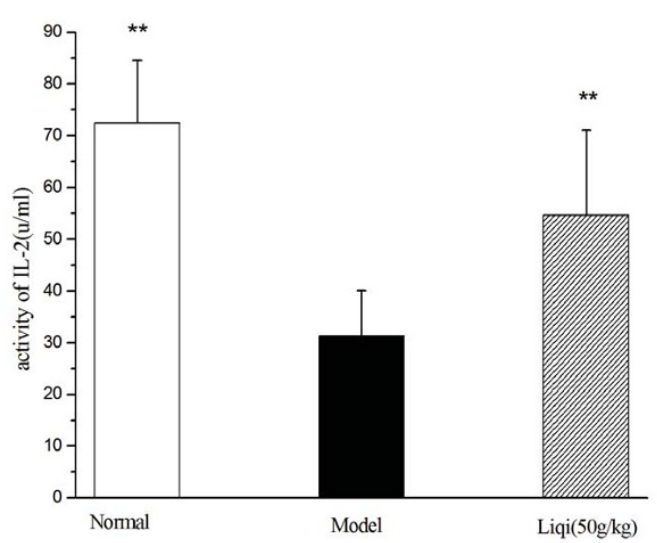

Figure 3

Effect of Liqi on IL-2 activity in tumor-bearing mice. Sarcoma 180 tumor cells were subcutaneously implanted (2 $\times 10^{6}$ cells suspended in $50 \mu \mathrm{l}$ of PBS) in the right axillary region of syngeneic BALB/c mice. After $24 \mathrm{~h}$, liqi (50 g/ $\mathrm{kg}$ ) was administrated daily by gavage for 12 days. IL-2 production and activity in splenocyte supernatants were tested using an IL-2-dependent CTLL-2 cell proliferation assay. Results are expressed as the mean \pm S.D. of 12 mice. **P $<0.01$, compared with untreated control of tumor-transplanted animals (model group). The normal group indicates healthy animals without tumor xenograft for comparison.

which might be related to its inhibition of platelet aggregation and normalization of the balance between $\mathrm{TXA}_{2}$ and $\mathrm{PGI}_{2}$. Furthermore, liqi inhibited the human gastric carcinoma growth in xenografted mice. We demonstrated that liqi has an anti-tumor effect and this effect may be related to immune regulation and anticoagulation.

Previous reports have shown that the constituents of liqi had an anti-tumor effect in vitro. We have shown that treatment with liqi inhibited tumor growth in vivo. We found that liqi arrested the proliferation of the human gastric carcinoma cell line SGC-7901 from xenografted mice in the G0/G1 phase and reduced the proportion of cells in the $\mathrm{S}$ and $\mathrm{G} 2 / \mathrm{M}$ phases (mitotic/dividing phases).

Although the mechanisms underlying liqi's anti-tumor effect may be complex, our findings demonstrated that this effect was most likely related to immune regulation. Host immunity is implicated in the development and progression of malignant disease. Mice with tumors show a change in T lymphocyte subpopulations and NK cell activity. T cells can affect tumor cells directly or can act indirectly by producing cytokines that amplify cytotoxic $\mathrm{T}$ lymphocyte responses or activate NK cells and macrophages. Experimental studies have outlined the critical 


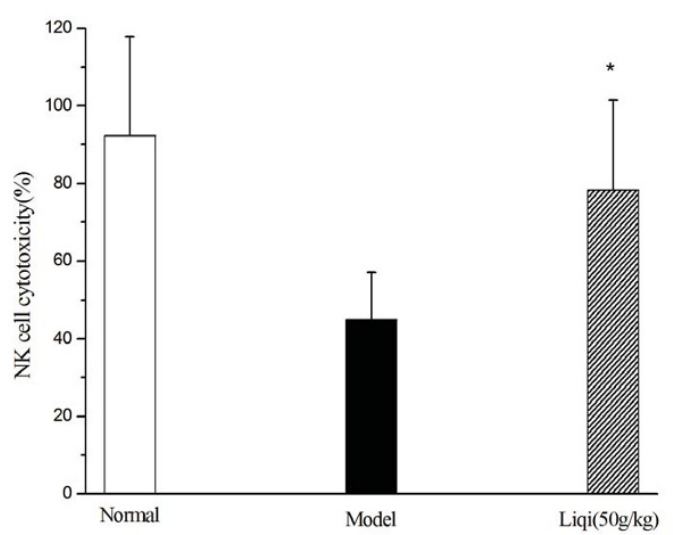

\section{Figure 4}

Effect of Liqi on NK cell cytotoxicity in tumor-bearing mice. Sarcoma 180 tumor cells were subcutaneously implanted $\left(2 \times 10^{6}\right.$ cells suspended in $50 \mu \mathrm{l}$ of PBS $)$ in the right axillary region of syngeneic BALB/c mice. After $24 \mathrm{~h}$, liqi $(50 \mathrm{~g} / \mathrm{kg}$ ) was administrated daily by gavage for 12 days. NK cell cytotoxicity was tested using YAC-I cells as target cells. $\mathrm{LDH}$ in culture supernatants was determined using the LDH Cytotox assay kit according to the manufacturer's instructions. Results are expressed as the mean \pm S.D. of 12 mice. $* \mathrm{P}<0.05$, compared with untreated control of tumor-transplanted animals (model group). The normal group indicates healthy animals without tumor xenograft for comparison.

role of CD4+ and CD8+ T cells and NK cells in mediating anti-tumor immunity [17-20]. The present study confirms the decrease in the ratio of CD4+/CD8+ with increasing tumor burden, which appeared to result mainly from a decrease in CD4+ T cells and an increase in CD8+ T cells. However, the results also showed that the number of CD4+ T cells and the CD4+/CD8+ ratio increased significantly after administration of liqi, while the number of CD8+ cells decreased. This finding indicates that liqi can regulate the disordering of $\mathrm{T}$ lymphocyte subsets and improve the immune response.

We also found that administering liqi increased the activity of NK cells in tumor-bearing mice. NK cells are the major mediators of the innate anti-tumor immune responses; they eradicate tumors by recognizing stressinducible ligands on tumors and execute tumor cells with perforin and granzyme in vivo [21]. NK cells eradicate solid tumors by apoptosis [21]. Liqi augments the cytotoxic potential of NK cells in vivo. Our data show that liqi reversed tumor-mediated suppression of NK cell cytotoxicity.

We found that the anti-tumor activity of liqi might also be related to its regulatory effects on IL- 2 and TNF- $\alpha$, both of which play important roles in cancer therapy $[22,23]$. IL-

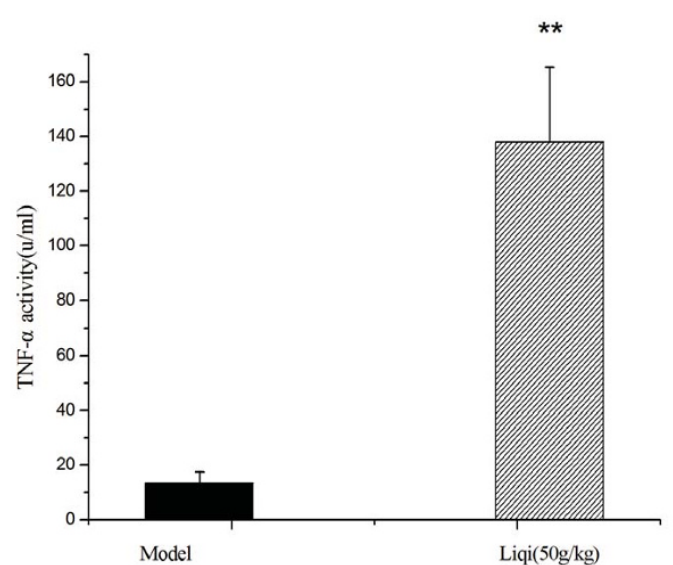

Figure 5

Effect of Liqi on TNF- $\alpha$ activity in tumor-bearing mice. Sarcoma 180 tumor cells were subcutaneously implanted $\left(2 \times 10^{6}\right.$ cells suspended in $50 \mu \mathrm{l}$ of PBS) in the right axillary region of syngeneic BALB/c mice. After $24 \mathrm{~h}$, Liqi $(50 \mathrm{~g} / \mathrm{kg})$ was administrated daily by gavage for 12 days. Then tumor-bearing BALB/c mice received $20 \mu \mathrm{g} / 0.2 \mathrm{ml}$ of LPS intravenously. After I.5 h, blood samples were collected from the mice's orbital plexuses. TNF activity was determined by a cytotoxicity assay on L929 cells. The percent cytotoxicities were plotted against the logarithm of sample quantity. One unit of TNF activity was defined as the sample quantity required to achieve $50 \%$ cytotoxicity in the reaction. Results are expressed as the mean \pm S.D. of 12 mice. $* * \mathrm{P}<$ 0.01 , compared with untreated control of tumor-transplanted animals (model group).

2 has an anti-tumor effect because of its immune-regulating function [24], TNF- $\alpha$ had an anti-tumor activity against sarcoma 180 . In addition to direct cytotoxicity against tumor cells, TNF induced a host-mediated factor which contributed to the anti-tumor effects [25]. Rychly J et al. [26] also demonstrated that TNF- $\alpha$ induced strong necrosis in sarcoma 180 in vivo and showed total regression. The infiltration of inflammatory cells was observed in the sarcoma 180 tumor. Their result suggested that cell infiltration may be of importance for tumor regression. A synergistic anti-tumor effect has been observed when TNF- $\alpha$ is combined with IL-2 [27]. We demonstrate that liqi can stimulate the production and activity of IL-2 and TNF- $\alpha$ in mouse Sarcoma 180 tumor-bearing mice.

Furthermore, we demonstrated that liqi inhibited metastasis of Lewis lung carcinomas. Metastasis is the major cause of death from cancer. Tumor-induced platelet aggregation is believed to protect tumor cells from immunological assault in circulation [28]; platelets protect tumors from TNF- $\alpha$-mediated cytotoxicity [29]. Platelets also facilitate the adhesion of tumor cells to the vascular endothelium and release a number of growth factors that 


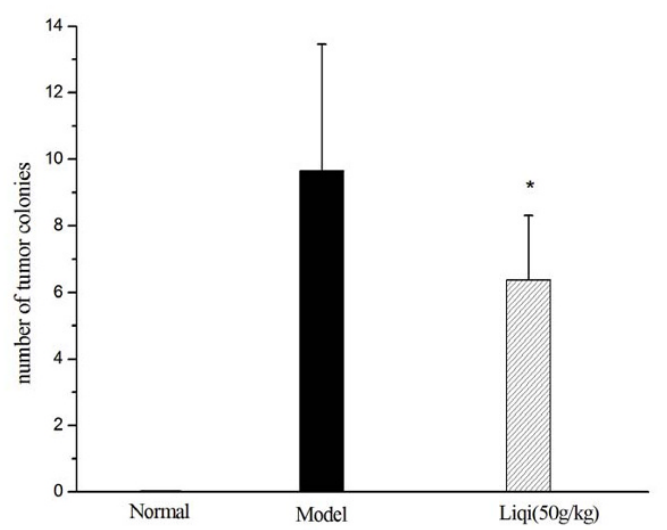

Figure 6

Effect of Liqi on metastasis of tumor cells to the lungs. Lewis lung carcinoma cells were subcutaneously implanted $\left(2 \times 10^{6}\right.$ LLC tumor cells suspended in $50 \mu \mathrm{l}$ of PBS) in the right axillary region of syngeneic C57BL/6 mice. After $24 \mathrm{~h}$, Liqi $(50 \mathrm{~g} / \mathrm{kg})$ was administrated daily by gavage for 21 days. Lungs were removed and fixed in $4 \%$ formalin. Tumor colonies were counted under microscope $(\times 200)$. Results are expressed as the mean \pm S.D. of 12 mice. * $P<$ 0.05 , compared with model group. The normal group indicates healthy animals without tumor xenograft for comparison.

promote tumor growth [30]. Recently, it has been reported that platelets contribute to tumor-induced angiogenesis by releasing angiogenic growth factors, such as vascular endothelial growth factor [31]. Our results demonstrated that platelet aggregation was increased in $\mathrm{C}_{57} \mathrm{BL}$ mice with Lewis lung carcinomas, and liqi inhibited platelet aggregation in these mice.

$\mathrm{PGI}_{2}$, a potent vasodilator and inhibitor of platelet aggregation, is an important antithrombotic mediator in vivo [32]. It also inhibits carcinogenesis [33]. Conversely, $\mathrm{TXA}_{2}$ stimulates platelet aggregation and amplifies the response to other platelet agonists [34]. We demonstrated that the level of $\mathrm{PGI}_{2}$ in serum was decreased and the level of $\mathrm{TXA}_{2}$ was increased, which resulted in an increased $T / P$ ratio in

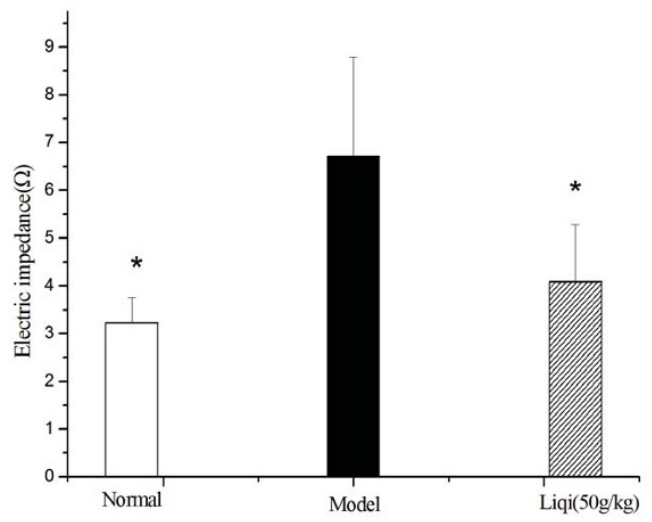

Figure 7

Effect of Liqi on platelet aggregation in tumor-bearing mice. Lewis lung carcinoma cells were subcutaneously implanted $\left(2 \times 10^{6}\right.$ LLC tumor cells suspended in $50 \mu \mathrm{l}$ of PBS) in the right axillary region of syngeneic C57BL/6 mice. After $24 \mathrm{~h}$, Liqi $(50 \mathrm{~g} / \mathrm{kg}$ ) was administrated daily by gavage for 21 days. Platelet aggregation was monitored by measuring electric impedance using a whole-blood aggregometer. Results are expressed as the mean \pm S.D. of 12 mice. *P < 0.05 , compared with untreated control of tumor-transplanted animals (model group). The normal group indicates healthy animals without tumor xenograft for comparison.

$\mathrm{C}_{57} \mathrm{BL}$ mice with Lewis lung carcinomas. However, Liqi treatment inhibited the increase in the $\mathrm{T} / \mathrm{P}$ ratio.

\section{Conclusion}

In summary, we demonstrated for the first time that liqi has a significant inhibitory effect on tumor growth in vivo. This inhibition may be related to the immunoregulatory effects of liqi, such as stimulating IL- 2 and TNF- $\alpha$ production and activity and increasing the ratio of $\mathrm{CD} 4+$ to CD8+ T lymphocytes and the activity of NK cells. These data lead us to propose that the anticancer function of liqi is underpinned by the improvement of immune function. Furthermore, liqi has a significant inhibitory effect on tumor metastasis, which is most likely related to its anticoagulation effects. These findings provide an experimental basis for the use of liqi for tumor therapy. The findings

Table 4: Effect of Liqi on $\mathrm{TXA}_{2}$ and $\mathrm{PGI}_{2}$ in tumor-bearing mice.

\begin{tabular}{|c|c|c|c|c|}
\hline Groups & Doses (g/kg) & $\mathrm{TXB}_{2}(\mathrm{pg} / \mathrm{ml})$ & 6-Keto-PGF $F_{1 \alpha}(p g / m I)$ & $\mathbf{T} / \mathbf{P}$ \\
\hline Normal & 0 & $1011.64 \pm 102.57^{* *}$ & $404.12 \pm 51.33^{* *}$ & $2.72 \pm 0.78^{* *}$ \\
\hline Model & 0 & $1583.5 \pm 102.45$ & $178 \pm 31.12$ & $8.76 \pm 1.67$ \\
\hline Liqi & 50 & $\mid \mathrm{I} 85.43 \pm 148.45^{* *}$ & $323.15 \pm 104.25^{* *}$ & $4.81 \pm 1.22^{* *}$ \\
\hline
\end{tabular}

Each group consists of 12 mice. Results are presented as mean \pm S.D. $* * P<0.01$, compared with model group. 
of our study may shed light on the pharmacologic basis for the clinical application of traditional Chinese medicine in treating cancer.

\section{Competing interests}

The authors declare that they have no competing interests.

\section{Authors' contributions}

DBJ carried out the studies, performed the statistical analysis and drafted the manuscript. JY carried out the study design, participated in the studies and drafted the manuscript. BWQ conceived of the study and participated in its design and coordination. YMJ participated in cell cycle and peripheral blood $\mathrm{T}$ lymphocyte subsets analysis. All authors read and approved the final manuscript.

\section{Acknowledgements}

The authors thank Professor Er Xin Yu, Yong Xiang Zhang and Yuan Fu Ji for their support.

\section{References}

I. Kellof G]: Perspective on cancer chemoprevention research and drug development. Adv Cancer Res 2000, 78:199-334.

2. Xu GH, Kim JA, Kim SY, Ryu JCh, Kim YS, Jung SH, Kim MK, Lee SH: Terpenoids and Coumarins Isolated from the Fruits of Poncirus trifoliata. Chem Pharm Bull 2008, 56:839-842.

3. Mimaki $Y$, Kttroda M, Yokosuka A: Triterpenes and triterpene saponins from the stems of Akebia Trifoliate. Chem Pharm Bull 2003, 51:960.

4. Gao Y, Huang H, Xu H, Diao Y, Dong Z: Studies on the chemical constituents of Citrus medica var. sarcodactylis. Zhong Yao Cai 2002, 25:639-640. (In Chinese).

5. Talwar KK, Singh IP, Kalsi PS: A sesquiterpenoid with plant growth regulatory activity from Saussurea lappa. Phytochemistry 1992, $31: 336-338$.

6. Jayaprakasha GK, Mandadi KK, Poulose SM, Jadegoud Y, Nagana Gowda GA, Patil BS: Inhibition of colon cancer cell growth and antioxidant activity of bioactive compounds from Poncirus trifoliata (L.) Raf. Bioorg Med Chem 2007, I 5:4923-4932.

7. Yi JM, Kim MS, Koo HN, Song BK, Yoo YH, Kim HM: Poncirus trifoliata fruit induces apoptosis in human promyelocytic leukemia cells. Clin Chim Acta 2004, 340: I79- I85.

8. Loo WT, Chen JP, Chow LW, Chou JW: Effects of Shugansanjie Tang on matrix metalloproteinases $I, 3$ and 9 and telomerase reverse transcriptase expression in human breast cells in vitro. Biomed Pharmacother 2007, 6 I:601-605.

9. Ko SG, Kim HP, Jin DH, Bae HS, Kim SH, Park CH, Lee JW: Saussurea lappa induces G2-growth arrest and apoptosis in AGS gastric cancer cells. Cancer Lett 2005, 220: I I- I9.

10. Sun GP, Wang H, Xu SP, Shen YX, Wu Q, Chen ZhD, Wei W: Antitumor effects of paeonol in a HepA-hepatoma bearing mouse model via induction of tumor cell apoptosis and stimulation of IL-2 and TNF- $\alpha$ production. Eur J Pharmacol 2008, 584:246-252.

II. Li C, Kumar S, Ponting J, Carette M, Allan E: Glucosaminylmuramyl dipeptide (GMDP) modulates endothelial cell activities in vitro but has no effects on angiogenesis in vivo. Inflamm Res 1997, 46:348-353.

12. Zhang LL, Wei W, Yan ShX, Hu XY, Sun WY: Therapeutic effects of glucosides of Cheanomeles speciosa on collagen-induced arthritis in mice. Acta Pharmacol Sin 2004, 25:|495-I50I.

13. Sarangi I, Ghosh D, Bhutia SK, Mallick SK, Maiti TK: Anti-tumor and immunomodulating effects of Pleurotus ostreatus myceliaderived proteoglycans. Int Immunopharmacol 2006, 6: I 287-I 297.

14. Wang YP, Li XY, Song ChQ, Hu ZB: Effect of astragaloside IV on $\mathrm{T}$, B lymphocyte proliferation and peritoneal macrophage function in mice. Acta Pharmacol Sin 2002, 23:263-266.

15. Kunita A, Kashima TG, Morishita Y, Fukayama M, Kato Y, Tsuruo T, Fujita N: The Platelet Aggregation-Inducing Factor Aggrus/
Podoplanin Promotes Pulmonary Metastasis. Am J Pathol 2007, I 70: I337-1347.

16. Furhashi N, Tsujiei M, Kimura H, Yajima A, Nagae H, Kimura C: Maternal and fetal atrial natriuretic peptide levels, maternal plasma rennin activity, angiotensin II, prostacyclin and thromboxane A2 levels in normal and preeclamptic pregnancies. Tohoku J Exp Med I99I, I 65:79-86.

17. Hung K, Hayashi R, Lafond-Walker A, Lowenstein C, Pardoll D, Levitsky $\mathrm{H}$ : The central role of CD4(+) T cells in the antitumor immune response. J Exp Med 1998, I 88:2357-2368.

18. Nishimura T, Iwakabe K, Sekimoto M, Ohmi Y, Yahata T, Nakui M, Sato T, Habu S, Tashiro $H$, Sato $M$, Ohta A: Distinct role of antigen-specific $T$ helper type I (ThI) and Th2 cells in tumor eradication in vivo. J Exp Med 1999, 190:617-627.

19. van den Broek MF, Kagi D, Zinkernagel RM, Hengartner H: Perforin dependence of natural killer cell-mediated tumor control in vivo. Eur J Immnol I995, 25( I I):35 I4-35I6.

20. Smyth MJ, Thia KY, Cretney E, Kelly JM, Snook MB, Forbes CA, Scalzo AA: Perforin is a major contributor to NK cell control of tumor metastasis. J Immunol 1999, I 62:6658-6662.

21. Varalakshmi Ch, Ali AM, Pardhasaradhi BVV, Srivastava RM, Singh S, Khar A: Immunomodulatory effects of curcumin: In-vivo. Int Immunopharmacol 2008, 8:688-700.

22. Tamada K, Chen L: Renewed interest in cancer immunotherapy with the tumor necrosis factor superfamily molecules. Cancer Immunol Immunother 2006, 55:355-362.

23. Glick RP, Lichtor T, Lin H, Tarlock K, Cohen EP: Immunogene therapy as a treatment for malignant brain tumors in youngmice. J Neurosurg 2006, 105:65-70.

24. Antony PA, Restifo NP: CD4+CD25+ T regulatory cells, immunotherapy of cancer, and interleukin-2. J Immunother 2005, 28: $120-128$.

25. Haranaka K, Satomi N, Sakurai A: Antitumor activity of murine tumor necrosis factor (TNF) against transplanted murine tumors and heterotransplanted human tumors in nude mice. Int J Cancer 1984, 34:263-267.

26. Rychly J, Knippel E, Krygier-Stojalowska A, Nizze H, Kuchnio M, Kraeft SK: DNA cytometric and histologic findings in mouse tumors(BP and SI80) with different response to treatment with tumor necrosis factor. Acta Oncol 1990, 29:47-5I.

27. Su Y, Wu YM: The study of synergistic cytotoxicity of tumor necrosis factor and interleukin-2 against lung adenocarcinoma cell. Chin J Cancer Res 2000, 19:779-78I.

28. Honn KV, Tang DG, Crissman JD: Platelets and cancer metastasis: a causal relationship? Cancer Metastasis Rev 1992, I I:325-35 I.

29. Philippe C, Philippe B, Fouqueray B, Perez J, Lebret M, Baud L: Protection from tumor necrosis factor-mediated cytolysis by platelets. Am J Pathol 1993, I43:1713-1723.

30. Mehta P: Potential role of platelets in the pathogenesis of tumor metastasis. Blood 1984, 63:55-63.

31. Verheul HM, Hoekman K, Lupu F, Broxterman HJ, Valk P van der, Kakkar AK, Pinedo HM: Platelet and coagulation activation with vascular endothelial growth factor generation in soft tissue sarcomas. Clin Cancer Res 2000, 6: I66-I7I.

32. Kobayashi T, Tahara Y, Matsumoto M, Iguchi M, Sano H, Murayama T, Arai H, Oida H, Yurugi-Kobayashi T, Yamashita JK, Katagiri H, Majima M, Yokode M, Kita T, Narumiya S: Roles of thromboxane A(2) and prostacyclin in the development of atherosclerosis in apoE-deficient mice. J Clin Invest 2004, I I 4:784-794.

33. Keith RL, Miller YE, Hoshikawa Y, Moore MD, Gesell TL, Gao B, Malkinson AM, Golpon HA, Nemenoff RA, Geraci MW: Manipulation of Pulmonary Prostacyclin Synthase Expression Prevents Murine Lung Cancer. Cancer Res 2002, 62:734-740.

34. Cheng Y, Austin SC, Rocca B, Koller BH, Coffman TM, Grosser T, Lawson JA, FitzGerald GA: Role of prostacyclin in the cardiovascular response to thromboxane A2. Science 2002, 296:539-54I.

\section{Pre-publication history}

The pre-publication history for this paper can be accessed here:

http://www.biomedcentral.com/1472-6882/9/20/prepub 